\title{
Gross Motor Function of A Child With Neurodegeneration With Brain Iron Accumulation (NBIA)
}

\author{
Função Motora Grossa de uma Criança com Neurodegeneração com Acúmulo Cerebral de Ferro (NBIA) \\ Rubia do Nascimento Fuentefria ${ }^{1}$, Franciane Barbieri Fiório ${ }^{2}$, Daniela \\ Sposito Dias', Alexandre Meneghello Fuentefria ${ }^{4}$
}

\begin{abstract}
Introduction. Neurodegeneration with brain iron accumulation (NBIA) involves a group of progressive extrapyramidal disorders characterised by iron accumulation in the brain. Objective. to describe the gross motor function of a child with clinical diagnosis of NBIA. Method. This is a case report involving a 7-year-old child and clinical diagnosis of NBIA. This study evaluated the history of the disease and the neuromotor functions of the child using a neurological physiotherapy evaluation form. The GMFM - Gross Motor Function Measure, a system of quantitative assessment of gross motor function in five broad dimensions, was applied. Case Presentation. Magnetic resonance imaging (MRI) showed the eye-of-the-tiger sign in the medial globus pallidus. Clinical examination presented extrapyramidal signs like dystonia, choreoathetosis, dysarthria and visual impairment. In this case, the combination of clinical and MRI findings was consistent with NBIA. Results. In the A dimension (down and roll) of GMFM, the child achieve a score of 39 points ( $76 \%$ of the gross motor function); in the $\mathrm{B}$ dimension (sit) she achieve a total score of 60 points (30\% of the function); in the $\mathrm{C}$ dimension (crawl and kneel) she achieve a score of 1 point ( $2 \%$ of the function); in the $\mathrm{D}$ dimension (standing position) and in the E dimension (walk, run and jump) she did not score in any item. Conclusion. The significant deficit in proximal stability and frequent extensor dystonic spasms affected the child's functional performance.
\end{abstract}

Keywords. Pantothenate Kinase-Associated Neurodegeneration, Muscle Rigidity, Dystonia.

Citation. Fuentefria RN, Fiório FB, Dias DS, Fuentefria AM. Gross Motor Function of A Child With Neurodegeneration With Brain Iron Accumulation (NBIA).

\section{RESUMO}

Introduçáo. Neurodegeneração com acúmulo cerebral de ferro (NBIA) envolve um grupo de desordens extrapiramidais progressivas caracterizadas pelo acúmulo de ferro no cérebro. Objetivo. Descrever a funçáo motora grossa de uma criança com 7 anos de idade, com diagnóstico clínico de NBIA. Método. Trata-se de um relato de caso envolvendo uma criança do sexo feminino, com 7 anos de idade e diagnóstico clínico de NBIA. Foi coletada a história da doença e realizado exame neuromotor utilizando uma ficha de avaliação fisioterapêutica. O GMFM - Medição da Função Motora Grossa, um sistema de avaliação quantitativa da função motora grossa em cinco dimensóes, foi aplicado. Apresentaçáo do Caso. Ressonância Magnética (RM) mostrou o sinal do olho-de-tigre no globo pálido medial. O exame clínico apresentou sinais extrapiramidais como distonia, coreoatetose, disartria e deficiência visual. Neste caso, a combinação de achados clínicos e da RM foi consistente com NBIA. Resultados. $\mathrm{Na}$ dimensão A (deitar e rolar) do GMFM, a criança alcançou um escore de 39 pontos (76\% da função motora grossa); na dimensão B (sentar) ela alcançou um escore total de 60 pontos (30\% da funçáo), na dimensão $\mathrm{C}$ (engatinhar e ajoelhar) ela alcançou um escore de 1 ponto ( $2 \%$ da função), na dimensão $\mathrm{D}$ (em pé) e na dimensão $\mathrm{E}$ (andar, correr e pular) ela não pontuou em nenhum item. Conclusáo. $\mathrm{O}$ déficit significativo na estabilidade proximal e os espasmos distônicos extensores frequentes afetaram o desempenho funcional da criança.

Unitermos. Neurodegeneração Associada a Pantotenato-Quinase, Rigidez Muscular, Distonia.

Citação. Fuentefria RN, Fiório FB, Dias DS, Fuentefria AM. Função Motora Grossa de uma Criança com Neurodegeneração com Acúmulo Cerebral de Ferro (NBIA).
Trabalho realizado na Universidade Comunitária da Regiáo de Chapecó, UNOCHAPECÓ, Chapecó-SC, Brasil.

1.Fisioterapeuta, Doutoranda do Programa de Pós-Graduaçấo em Saúde da Criança e do Adolescente da Universidade Federal do Rio Grande do Sul UFRGS, Porto Alegre-RS, Brasil.

2.Fisioterapeuta, Mestre em Engenharia Biomédica, Docente no Curso de Graduação em Fisioterapia da Universidade Comunitária da Região de Chapecó - UNOCHAPECÓ, Chapecó-SC, Brasil.

3.Fisioterapeuta, Mestre em Envelhecimento Humano, Docente no Curso de Graduação em Fisioterapia da Universidade do Contestado - UnC, Concórdia-SC, Brasil.

4.Farmacêutico, Doutor em Ciências, Docente no Departamento de Análises da Universidade Federal do Rio Grande do Sul, UFRGS, Porto Alegre-RS, Brasil.
Endereço para correspondência: Rubia N Fuentefria Serviço de Neonatologia do Hospital de

Clínicas de Porto Alegre, sala 1123

Ramiro Barcelos, 2350, Santa Cecília CEP 90035-903, Porto Alegre-RS, Brasil. E-mail: rubianascif@gmail.com

Relato de Caso Recebido em: 12/08/13 Aceito em: 08/10/13 Conflito de interesses: nấo 


\section{INTRODUCTION}

Neurodegeneration with brain iron accumulation (NBIA) involves a group of progressive extrapyramidal disorders characterised by iron accumulation in the brain. The term NBIA encompasses the variety of disorders previously called Hallervorden-Spatz syndrome, as well as additional disorders of high brain iron level ${ }^{1}$.

The major form of NBIA is pantothenate kinase associated neurodegeneration, or PKAN, caused by mutations in the PANK2 gene found in approximately $50 \%$ of the cases ${ }^{2}$. The PKAN is characterized by dystonia, pigmentary retinopathy and optic atrophy in children and neuropsychiatric defects in adults, in concert with a specific pattern on Magnetic Resonance Imaging (MRI) of the brain ${ }^{3,4}$. This virtually pathognomonic radiographic abnormality, called the eye-of-the-tiger sign, comprises hyperintensities within a hypointense medial globus pallidus on T2-weighted images ${ }^{1,5}$. Pantothenate kinase is essential to coenzyme A biosynthesis, and PANK2 is targeted to mitochondria, a feature that distinguishes it from the three other human pantothenate kinase homo$\operatorname{logs}^{6}$. Three types of PKAN disease are defined by the onset of symptoms; early-onset (before the age of 10), lateonset (between the age of 10 and 18), and adult onset. Late onset and adult types are more slowly progressive ${ }^{2}$.

The conventional diagnosis of the disease is obtained by the MRI finding of high intensity bilateral signal in the globus pallidus surrounded by low intensity signal areas ${ }^{4,5}$. Pathologic iron deposition in the globus pallidus and zona reticularis of the substantia nigra is supposed to be important in the pathophysiology ${ }^{3}$. The genetic diagnosis by means of gene amplification and sequencing revealed homozygous 2 base pair deletion in Exon 2 of the PANK gene (692-693 deletion) leading to its frame shift and protein premature truncation ${ }^{1,7}$. Patients with NBIA have a combination of motor symptoms - notably dystonia, parkinsonism, choreoathetosis, corticospinal tract involvement, optic atrophy, pigmentary retinopathy and cognitive impairment $\mathrm{t}^{4,8}$.

The objective of this report is to describe the gross motor function of a 7-year-old child with clinical diagnosis of NBIA, in Santa Catarina State, Brazil.

\section{METHOD}

This is a case report of a 7-year-old child with clinical diagnosis of NBIA, in the city of Chapecó in southern Brazil. This case report was approved by the Ethics Committee of UNOCHAPECÓ (protocol number 105/10).

An interview was conducted with the mother in order to know the history of the disease in the pre, peri and postnatal period and neurological examinations performed. We used a neurological physiotherapy evaluation form for the collection of information and the neurological physiotherapy assessment. The GMFM - Gross Motor Function Measure was applied in order to obtain data about the gross motor function and to assist in the preparation of goals and a treatment plan for the child. The GMFM is a system of quantitative assessment of motor function in five broad dimensions.

\section{CASE PRESENTATION}

A seven-year-old girl, first child of unrelated parents, presenting NBIA symptoms without any family history neither associated with neurological disorders nor inherited and there were no complications in the prenatal period either. At birth she had congenital dislocation of left hip, requiring four surgeries to perform correction, with the first occurring at 6 months of age and the last at the age of 4 .

The child began to walk independently at 1 year and 4 months old, but it was interrupted by surgical procedures. Frequent falls during walking and deficits in motor coordination and balance were observed during her first five years. The development of verbal language was characterized by the production of few words and difficulty in articulating them. She began to control her sphincters at the age of 5 and also started having hand tremors and more evident disorders in verbal language, motor coordination and balance.

Suddenly, at the age of 6 she developed digitigrade walking associated with upper limb flexion and hyperextension of the spine, these signs gradually progressed to upper and lower limbs choreoathetoid movements, generalized dystonia, affecting mainly cervical and trunk control, dysarthria and orofacial dyskinesia. She devel- 
oped predominantly limb extensor posture, presenting opisthotonus, so that, losing the functional ability to sustain herself sitting, standing without support and walking independently.

Magnetic resonance imaging (MRI) of the brain was performed and showed the "Eye of the Tiger" appearance, a bilateral high signal intensity in the globus pallidus surrounded by low signal intensity areas on T2-weighted MRI (Fig. 1). No molecular studies were available.

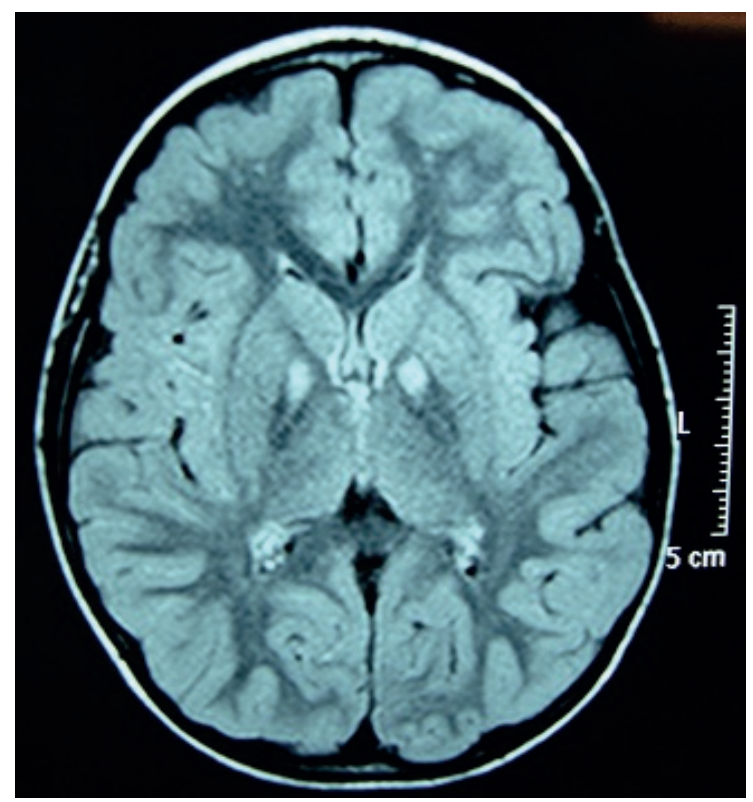

Figure 1. T2-weighted magnetic resonance imaging revealing the "eye of the tiger" sign in the globus pallidus.

\section{RESULTS}

In the physiotherapeutic examination, performed at the age of 6 , the child was conscious, responsive to verbal stimuli, although communicating with difficulties (dysarthria) and with few words. Involuntary movements of the face were noted, constantly changing facial expression and sometimes manifesting sardonic laughter. The child used a nasogastric tube, did not have sphincter control and was dependent for activities of daily living. There was the presence of severe generalized dystonic spasms, as well as upper and lower limbs choreoathetoid exacerbation of movements during the act of holding objects or voluntary movement. Deep tendon reflexes and the cutaneous plantar reflex were positive. The visual examination showed bilateral nystagmus and, according to her mother, the child has difficulty to adapt to the dark associated with worsening of vision at night.

Assessment of gross motor function: The dimension A of the GMFM refers to the ability to down and roll and comprises 17 items. The child can achieve a total score of 51 points, which represents $100 \%$ skill in this dimension. In this evaluation, the child had a score of 39 points, which represents $76 \%$ of the gross motor function. The activities that did not score in this dimension reflect the difficulty of the postural control in prone position. In this position, the abnormal tonic activity (dystonia) influenced the score of the items related to the ability to stay in prone position on the forearms, distribute the weight on the contralateral arm and to be able to perform the functional reach. In an attempt to perform this activity, the child has severe extensors dystonic spasms in the cervical, trunk and limbs. The child could not roll actively from supine to prone, however she could move from supine to right lateral position.

The dimension B of the GMFM refers to the ability to sit and comprises 20 items. The child can achieve a total score of 60 points. In this evaluation, the child had a score of 18 points, which represent 30\% of the gross motor function in this dimension. Activities that did not score in this dimension showed that the child could not remain in the seated position with arms free and could not perform functional reach. Other important items that did not score demonstrated that the child could not remain in the seated position on the bench, keeping arms and legs free. For scored items, the highlight was the ability to be in supine position, rolling to the right and sitting down, however with severe influence of abnormal movement patterns. The child could remain in the seated position on the floor supported by her arms for $5 \mathrm{sec}$ onds, after that she fell back due to the lack of stability of the trunk, shoulder girdle and upper limbs.

The dimension C of the GMFM refers to the ability to crawl and kneel and comprises 14 items, which can achieve a total score of 42 points. In this evaluation, the child had a score of 1 point, which represents $2 \%$ of the gross motor function in this dimension. The only activity scored in this dimension refers to the act of creeping forward in a prone position. The remaining items were not scored. The dimension D refers to skills in the standing 
position and consists of 13 items, reaching a total score of 39 points. The Dimension E refers to the ability to walk, run and jump and has 24 items, which can achieve a total of 72 points. In this evaluation, the child did not score in any item of these dimensions.

\section{DISCUSSION}

We reported a case of Hallervorden-Spatz syndrome, currently called Neurodegeneration with brain iron accumulation (NBIA). Patients with previous diagnosis of Hallervorden-Spatz syndrome today are included in this group of genetic diseases with progressive extrapyramidal disorders ${ }^{1}$. The NBIA is characterized by iron deposition in the brain usually in the basal ganglia associated with neuronal death ${ }^{2,8}$. The most prevalent form of neurodegeneration with iron accumulation in the brain is the Pantothenate kinase associated with neurodegeneration (PKAN). This is a rare autosomal recessive neurodegenerative disease characterized predominantly by extrapyramidal dysfunction resulting from mutations in PANK2 (pantothenate kinase 2) gene e $^{1,2,4,6}$.

Considering the four subtypes of NBIA (pantothenate kinase associated neurodegeneration, neuroferritinopathy, infantile neuroaxonal dystrophy and aceruloplasminemia), the pantothenate kinase associated neurodegeneration is the subtype cited as the previous Hallervorden-Spatz ${ }^{2}$, which is likely the subtype of the reported case. Most cases of PKAN are relatively similar presenting early onset (usually before the age of 6) and rapid progression ${ }^{1,8}$. In this case, progressive symptoms of orofacial dyskinesia, dysarthria, generalized dystonia and choreoathetoid movements, which started before the age of 6, and the presence of "Eye of the Tiger" appearance on the MRI are aspects of clinical and neuroimaging findings of NBIA and suggestive of PKAN type.

Delayed motor and language development and frequent falls are described in reported cases, such as progressive dystonia involving the neck, trunk and limbs, dysarthria and loss of functional abilities ${ }^{1,9-11}$. Symptoms usually begin in the first decade of life with an extrapyramidal motor disorder and walking difficulty ${ }^{4}$. Symptoms including rigidity of extremities, slow movements, dystonia, choreoathetosis and tremor are prominent ${ }^{4}$.

In this case there was the presence of bilateral equinovarus, severe shortening of triceps surae muscle tendon and loss of movement of ankle dorsiflexion. Muscle shortening affecting the lower limbs, particularly triceps surae have been cited in cases of PKAN ${ }^{8,10}$. The child has severe pain in the tibiotarsal joint, especially when involving dystonia of the lower limbs. Muscle spasms caused hyperextension of the neck, trunk and lower limbs, leaving her in opisthotonus and in abnormal patterns of axial and appendicular posture, causing pain and limitations in motor function.

Through the GMFM was possible to identify that the child had some motor ability related to the first measurement dimensions (A, B, C), with the absence of any scores in the dimensions $\mathrm{D}$ and $\mathrm{E}$. This demonstrated her motor limitations mainly in high postures, with a significant deficit in proximal stability and generalized increase of dystonic spasms, not allowing the active and independent posture maintenance. The incapacity to maintain the sitting posture and ambulation as well as the dependence for daily living activities and functional limitations are cited in cases of PKAN with prolonged dystonic spasms involving the limbs, trunk, face and neck ${ }^{6,11,12}$.

Progressive dystonia is one of the extrapyramidal symptoms that severely affects the functional capacity of the child ${ }^{6,11,12}$. It is a common clinical feature among patients with this disease and its progression often causes serious complications, such as feeding problems, repeated aspiration and asphyxia ${ }^{6}$. Muscular shortenings, bone deformities and pain are also cited as secondary complications related to frequent dystonic spasms ${ }^{11}$. There is also a great risk of developing cervical spondylosis and myeloradiculopathy. The repetitive dystonic movements, especially of head and neck, can lead to excessive stress on the spine, resulting in early degenerative disorders and new neurological signs ${ }^{6,13}$. In this case there was the presence of these signs and symptoms, especially the frequent dystonic spasms, feeding problems, muscular shortenings, bone deformities and pain.

There is no definitive treatment for this disease ${ }^{8}$. Death usually occurs from complications of neurodegenerative disorders, including aspiration, pneumonia and malnutrition ${ }^{1,6}$, usually in the second or third decade of life ${ }^{1,5}$. The disease usually continues for 10-12 years, but some reports describe patients who survived for 30 years ${ }^{12,14,15}$. 
The use of drugs and surgical interventions are intended to palliation of symptoms ${ }^{1}$. In our case, the child used levodopa and carbidopa, but the combination of these two substances was not satisfactory. Then it was replaced by a drug which combines three active ingredients (levodopa / carbidopa / entacapone). Dystonia can be difficult to treat and drug therapy may have limited benefits ${ }^{6}$, however drugs to reduce dystonia are indicated in these cases and the most commonly used are anticholinergics ${ }^{4}$. Furthermore, the botulinum toxin can be injected in the severely affected muscles to relieve dystonia ${ }^{16}$. In this case, the toxin was performed bilaterally in the gastrocnemius and soleus muscles in an attempt to reduce the dystonia in lower limbs. The bilateral pallidal deep brain stimulation also has been studied in treatment of patients with PKAN, with outcome favorable in the management of dystonia ${ }^{15,17}$.

Physical therapy interventions with a frequency of three times a week during 6 months were associated with drug treatment. This association provided a positive impact on the child's dystonia reducing the frequency and intensity of extensor spasms. Position of body segments, symmetrical distribution of weight in the supine, inhibition of dystonic spasms, muscle passive stretching, facilitation of voluntary movements and postural reactions in the seated position were some of the physical therapy techniques used in this case.

The multidisciplinary approach involving physiotherapy, occupational therapy, speech therapy and psychology professionals is of the utmost importance in monitoring patients with $\mathrm{NBIA}^{6}$, since generalised dystonia, rigidity, spasticity, ataxia, postural instability, bradikynesia, cognitive impairment, dysphagia and hypophonia are among the clinical findings of patients with this diagnosis ${ }^{18}$.

In this case, a multidisciplinary team composed of the doctor, physiotherapist, occupational therapist, psychologist, nutritionists, psychopedagogist and speech therapist accompanied the patient from diagnosis, giving the necessary support to the family understand and participate in the child's treatment. In physical therapy, the family of the child was always present interacting and participating of the treatment. This participation was very important for the child to accept the proposed activities.
The family of the child with neurodegenerative disease should be assisted by physiotherapy, receiving guidance on the proper placement, handling during activities of daily living and home exercises to maintain joint mobility and muscle flexibility. With the purpose of better functional condition of a child with a neurodegenerative disease, the proactive action of parents in the home environment is essential, directly reflecting in their psychomotor development.

The role of physical therapy has been rarely reported, but cases of this neurodegenerative disease with generalized dystonia, early onset and with rapid progression may obtain important benefits of physiotherapy maintaining the patience's quality of life and minimizing serious secondary complications.

\section{CONCLUSION}

The application of GMFM contributed in the evaluation and determination of the treatment goals. The GMFM identified limitations in the child's gross motor function, as well as her ability to roll and sit upright on the floor with armrest for 5 seconds. The significant deficit in proximal stability and frequent extensor dystonic spasms affected the functional performance of this child.

The impact of NBIA in motor function was identified through the GMFM, however because it is the report of a single case is not necessarily representative of what happens in other individuals affected by this disease.

\section{REFERENCES}

1.Gregory A, Polster BJ, Hayflick SJ. Clinical and genetic delineation of neurodegeneration with brain iron accumulation. Med Genet 2009;46:73-80. http://dx.doi.org/10.1136/jmg.2008.061929

2.McNeill A, Birchall D, Hayflick SJ, Gregory A, Schenk JF, Zimmerman EA, et al. T2* and FSE MRI distinguishes four subtypes of neurodegeneration with brain iron accumulation. Neurology 2008;70:1614-9.

http://dx.doi.org/10.1212/01.wnl.0000310985.40011.d6

3.Hickman SJ, Ward NS, Surtees RA, Stevens JM, Farmer SF. How broad is the phenotype of Hallervorden-Spatz disease? Acta Neurol Scand 2001;103:201-3. http://dx.doi.org/10.1034/j.1600-0404.2001.103003201.x

4.Clement F, Devos D, Moreau C, Coubes P, Destee A, Defebvre L. Neurodegeneration with brain iron accumulation: clinical, radiographic and genetic heterogeneity and corresponding therapeutic options. Acta neurol belg 2007;107:26-31. 
5.Boyacigil S, Tokoğlu F, Paşaoğlu E, Ardiç S, Comoğlu S, Saka M, Oztürk S. Hallervorden-Spatz disease. Australasian Radiology 1996;40:351-3.

http://dx.doi.org/10.1111/j.1440-1673.1996.tb00419.x

6.Chan KY, Lam CW, Lee LP, Tong SF, Yuen YP. Pantothenate kinase-associated neurodegeneration in two Chinese children: identification of a novel PANK2 gene mutation. Hong Kong Med J 2008;14:70-3.

7.Gregory A, Hayflick SJ. Neurodegeneration with brain iron accumulation. Folia Neuropathol 2005;43:286-96.

8.Sharma MC, Aggarwal N, Bihari M, Goyal V, Gaikwed S, Vaishya S, et al. Hallervorden spatz disease: MR and pathological findings of a rare case. Neurol India 2005;53:102-4.

http://dx.doi.org/10.4103/0028-3886.15072

9.Freeman K, Gregory A, Turner A, Blasco P, Hogarth P, Hayflick S. Intellectual and adaptive behaviour functioning in pantothenate kinase-associated neurodegeneration. J Intellect Disabil Res 2007;51:417-26.

http://dx.doi.org/10.1111/j.1365-2788.2006.00889.x

10.Kapoor S, Hortnagel K, Gogia S, Paul R, Malhotra V, Prakash A. Pantothenate Kinase Associated Neurodegeneration (Hallervorden - Spatz Syndrome). Indian J Pediatr 2005;72:261-3.

http://dx.doi.org/10.1007/BF02859271

11.Kyriagis M, Grattan-Smith P, Scheinberg A, Teo C, Nakaji N, Waugh M. Status dystonicus and Hallervorden-Spatz disease: Treatment with intrathecal baclofen and pallidotomy. J Paediatr Child Health 2004;40:322-5.

http://dx.doi.org/10.1111/j.1440-1754.2004.00374.x
12.Kruer C M, Hiken M, Gregory A, Malandrini A, Clark D, Hogarth P, et al. Novel histopathologic findings in molecularly-confirmed pantothenate kinaseassociated neurodegeneration. Brain 2011;134:947-58.

http://dx.doi.org/10.1093/brain/awr042

13.Fung GPG, Chan KY. Cervical myelopathy in an adolescent with Hallervorden-Spatz disease. Pediatr Neurol 2003;29:337-40.

http://dx.doi.org/10.1016/S0887-8994(03)00272-8

14.Gregory A, Hayflick SJ. Neurodegeneration with brain iron accumulation. Folia Neuropathol 2005;43(4):286-96.

15.Lim BC, Ki CS, Cho A, Hwang H, Kim KJ, Hwang YS, et al. Pantothenate kinase-associated neurodegeneration in Korea: recurrent R440P mutation in PANK2 and outcome of deep brain stimulation. Eur J Neurol 2012;19:556-61. http://dx.doi.org/10.1111/j.1468-1331.2011.03589.x

16.Justesen CR, Penn RD, Kroin JS, Egel RT. Stereotactic pallidotomy in a child with Hallervorden-Spatz disease. Case report. J Neurosurg 1999;90:551-4. http://dx.doi.org/10.3171/jns.1999.90.3.0551

17.Mahoney R, Selway R, Lin J. Cognitive functioning in children with pantothenate-kinase associated neurodegeneration undergoing deep brain stimulation. Dev Med Child Neurol 2011;53:275-9. http://dx.doi.org/10.1111/j.1469-8749.2010.03815.x

18.Camargos ST, Gurgel-Giannetti J, Lees A, Hardy J, Singleton A, Cardoso F. Low prevalence of PANK2 mutations in Brazilian patients with early onset generalized dystonia and basal ganglia abnormalities on MRI. J Neurol Neurosurg Psychiatry 2011;82:1059-60.

http://dx.doi.org/10.1136/jnnp.2009.200808 